\title{
PEMANFAATAN INTERNET SEBAGAI SALAH SATU SUMBER BELAJAR SISWA DAN GURU DI JURUSAN TEKNIK ELEKTRONIKA
}

\author{
Oleh \\ Anak Agung Gde Ekayana \\ Jurusan Pendidikan Teknik Elektro Fakultas Teknik dan Kejuruan \\ Universitas Pendidikan Ganesha \\ E-mail: gungekayana@yahoo.com
}

\begin{abstract}
ABSTRAK
Penelitian ini bertujuan untuk mengetahui seberapa besar pemanfaatan internet sebagai salah satu sumber belajar siswa dan guru beserta hambatan-hambatannya dalam penggunaan internet sebagai salah satu sumber belajar yang ditinjau dari proses pembelajaran, lingkungan dan sarana prasarana.

Penelitian ini merupakan penelitian deskriptif kuantitatif. Subjek penelitian sekaligus populasi penelitian yang terdiri atas siswa kelas X, XI, XII dan guru. Data primer diambil dengan metode kuesioner dengan angket sebagai instrumennya. Teknik analisa data yang digunakan dalam penelitian ini adalah teknik analisis deskriptif.

Hasil penelitian menunjukkan bahwa tingkat pemanfaatan internet sebagai salah satu sumber belajar siswa dan guru di SMK Negeri 2 Depok Sleman berada pada kategori tinggi, dengan ini berarti fasilitas yang ada disekolah maupun dilingkungan sekolah sudah digunakan dengan optimal untuk mencari referensi belajar maupun untuk pembelajaran di sekolah. Pemanfaatan internet sebagai salah satu sumber belajar untuk siswa kelas X; 75\%, siswa kelas XI ; 77.42\%, siswa kelas XII; 71.88\% dan guru; $66.66 \%$. Ini berarti bahwa sarana prasarana yang ada di sekolah sudah memadai untuk digunakan oleh para siswa dan guru dalam mencari sumber-sumber belajar. Selain dari segi sarana prasarana hambatan pemanfaatan internet sebagai sumber belajar juga berasal dari internet yaitu makin banyaknya situs pertemanan, seperti facebook, twitter, kaskus dan situs hiburan yang ada di internet yang mempengaruhi produktifitas belajar siswa maupun guru.

Kata kunci : Pemanfaatan Intenet, Sumber belajar, Analisis deskriptif
\end{abstract}

ABSTRACT
This study aims to determine how much use of the Internet as a source of learning of students and teachers as well as constraints in the use of the Internet as a source of learning in terms of teaching and learning, the environment and infrastructure in SMK N 2 Depok Sleman Yogyakarta. This research is quantitative descriptive. Research subjects at the same time study population consisted of students of class X, XI, XII and teachers. The primary data were taken by questionnaire with a questionnaire as an instrument. Data analysis technique used in this research is descriptive analysis techniques.

The results showed that the rate of use of the Internet as a source of learning of students and teachers at SMK N 2 Depok Sleman at high category, by means of existing facilities in schools and school environment has been used optimally to search for references to learn and learning in schools. Use of the Internet as a source of learning for students of class X; $75 \%$, a class XI student; $77.42 \%$, the students of class XII; $71.88 \%$ and teachers; $66.66 \%$. This means that the existing infrastructure in the schools are adequate for use by students and teachers in the search for learning resources. Apart from the infrastructure barriers to the use of the Internet as a source of learning also comes from the Internet that is the increasing number of social networking sites, such as facebook, twitter, kaskus and entertainment sites on the Internet that affect student learning and teacher productivity.

Keywords : Utilization of the Internet, learning resources, descriptive analysis 


\section{Pendahuluan}

Pada dunia pendidikan, internet akan sangat baik bila digunakan sebagai salah satu sumber belajar, seperti yang dikatakan oleh Arif Sudiman (1989) yang dikutip oleh Ahmad Rohani dan Abu Rahmadi (1991) bahwa segala sesuatu di luar peserta didik yang memungkinkan terjadinya proses belajar disebut sumber belajar. Guru akan lebih mudah memberikan informasi kepada siswanya dengan adanya internet ini, karena siswa hanya disuruh membuka suatu situs yang telah ditunjukkan oleh guru tentang situs yang relevan dengan pelajaran yang diajarkan sehingga dapat didiskusikan bersama sebagai bahan pelajaran.

Internet dapat dijadikan guru atau salah satu sumber belajar yang tak terbatas, karena di dalam internet juga tersedia bermacam-macam informasi misalnya lowongan pekerjaan, hotel, transportasi, hiburan dan lain-lain. Dengan internet siswa Jurusan Teknik Elektronika bisa mencari materi tentang cara-cara merawat dan mereparasi barang-barang elektronik, materi belajar tentang ilmu elektronika, datasheet mengenai suatu komponen elektronika, artikel tentang internet networking sampai software computer yang mendukung untuk kegiatan pembelajaran. Selain itu untuk memacu siswa agar tidak asing dengan internet, guru bisa memberikan soal atau tugas yang disampaikan melalui internet sehingga memaksa siswa untuk membuka internet. Dengan demikian proses pembelajaran akan lebih cepat dan efisien.

Pengaruh pendidikan dapat dilihat dan dirasakan secara langsung dalam perkembangan kehidupan masyarakat, kelompok, dan individu (Mulyasa, 2009) lebih lanjut dikemukakan Mulyasa bahwa pendidikan menentukan model manusia yang akan dihasilkannya. Pendidikan juga memberikan konstribusi yang sangat besar terhadap kemajuan suatu bangsa dan sarana dalam membangun watak bangsa. Oleh karena itu, para orang tua, guru, dan masyarakat harus benar-benar memberikan hal-hal yang positif yang mendukung perkembangan pendidikan.

Sekalipun para guru memahami bahwa strategi pembelajaran dengan memanfaatkan berbagai sumber belajar sangat menunjang atau membantu meningkatkan tingkat penguasaan peserta didik terhadap materi pelajaran, namun pada kenyataannya, masih banyak guru yang menyelenggarakan kegiatan pembelajaran tanpa didukung oleh berbagai sumber belajar. (Sudiarman Siahaan dan Rr Martiningsih, 2009:3)

Dengan melihat kenyataan di atas maka perlu diadakan penelitian mengenai Pemanfaatan Internet Sebagai Salah Satu Sumber Belajar Siswa dan Guru di Jurusan Teknik Elektronika, sehingga dengan hasil penelitian ini diharapkan dapat menjadi dasar 
pemikiran dan pertimbangan tentang pengadaan internet sebagai salah satu sumber belajar siswa dan guru.

\section{Metode Penelitian}

Penelitian tentang Pemanfaatan Internet Sebagai Salah Satu Sumber Belajar Siswa dan Guru di Jurusan Teknik Elektronika merupakan jenis penelitian deskriptif. Menurut Sukardi (2003: 162), bahwa penelitian deskriptif merupakan metode penelitian yang berusaha menggambarkan objek atau subjek yang diteliti sesuai dengan apa adanya, dengan tujuan menggambarkan secara sistematis fakta dan karakteristik objek yang diteliti secara tepat. Objek yang akan diteliti mengenai pemanfaatan internet sebagai salah satu sumber belajar siswa dan guru di Jurusan Teknik Elektronika. Pada penelitian ini pendekatan yang digunakan adalah pendekatan kuantitatif. Ditinjau dari wujud data dan teknik analisisnya termasuk dalam pendekatan kuantitatif, karena data yang diperoleh berupa angka-angka dan diselesaikan dengan metode statistika.

Dalam penelitian ini terdapat tiga variabel yang diteliti yaitu pemanfaatan oleh siswa ditinjau dari aspek kemampuan, proses pembelajaran serta lingkungan, pemanfaatan oleh guru dari aspek kemampuan, proses pembelajaran, lingkungan dalam kaitanya dengan penggunaan internet sebagai salah satu sumber belajar siswa dan guru, serta sarana prasarana yang mendukung, meliputi perangkat dan fasilitas internet.

Pada penelitian ini populasinya adalah seluruh guru dan seluruh siswa di Jurusan Teknik Elektronika SMK Negeri 2 Depok. Semua populasi di Jurusan Teknik Elektronika diambil sebagai objek penelitian. Siswa kelas I berjumlah 32 siswa, kelas II berjumlah 31 siswa, kelas III berjumlah 32 dan guru berjumlah 9 orang sehingga total dari seluruh siswa adalah 95 siswa dan total seluruh guru adalah 9 orang sehingga total keseluruhan 104 responden.

Teknik pengumpulan data yang digunakan dalam penelitian ini menggunakan metode kuesioner dengan alatnya berupa angket. Kuesioner ini juga sering disebut sebagai angket dimana dalam kuesioner tersebut terdapat beberapa macam pertanyaan yang berhubungan erat dengan masalah penelitian yang hendak dipecahkan, disusun, dan disebarkan ke responden untuk memperoleh informasi di lapangan. Pada penelitian ini angket yang digunakan adalah angket tertutup dan angket terbuka. Angket secara tertutup karena angket tersebut telah disediakan jawabannya sehingga responden tinggal memilih langsung jawabannya dan angket terbuka karena dalam menjawab pertanyaan yang direncanakan oleh peneliti responden diberikan kesempatan yang luas untuk menjawab pertanyaan tersebut. 


\section{Hasil dan Pembahasan}

Analisa kecenderungan Pemanfaatan Internet Sebagai Salah Satu Sumber Belajar Siswa ditinjau dari segi siswa dan guru dikategorikan menjadi 4 (Titin Hera Widi, 2009) dengan ketentuan sebagai berikut:

$\mathrm{Mi}=$ Mean ideal yang dicapai instrumen

$=\frac{1}{2}$ (skor ideal tertinggi + skor ideal terendah)

$\mathrm{SBi}=$ Simpangan baku ideal yang dicapai instrument

$=\frac{1}{6}$ (skor ideal tertinggi - skor ideal terendah $)$

Untuk penentuan kategori skor komponen-komponen digunakan norma berikut:

$$
\begin{array}{ll}
(\mathrm{Mi}+\text { 1,5 SBi) keatas } & \text { = Sangat baik/Sangat Tinggi } \\
\text { Mi sampai dengan }(\mathrm{Mi}+1,5 \mathrm{SBi}) & =\text { Cukup baik/Tinggi } \\
(\mathrm{Mi}-1,5 \mathrm{SBi}) \text { sampai dengan } \mathrm{Mi} & =\text { Kurang baik/Rendah } \\
(\mathrm{Mi}-1,5 \mathrm{SBi}) \text { ke bawah } & =\text { Tidak baik/Kurang }
\end{array}
$$

Skor ideal tertinggi $=172 ;$ skor ideal terendah $=43 ;$ rerata ideal $=107.5$; simpangan baku ideal $=21.5$

Diperoleh hasil bahwa Pemanfaatan Internet Sebagai Salah Satu Sumber Belajar Ditinjau Dari Siswa Kelas X yang memiliki kategori sangat tinggi sebanyak 0 siswa atau $0 \%$, kategori tinggi sebanyak 24 siswa atau $75 \%$, kategori rendah sebanyak 8 siswa atau $25 \%$, serta 0 siswa atau $0 \%$ dalam kategori kurang. Jadi secara umum Pemanfaatan Internet Sebagai Salah Satu Sumber Belajar Ditinjau Dari Siswa Kelas X mempunyai kecenderungan dalam kategori tinggi.

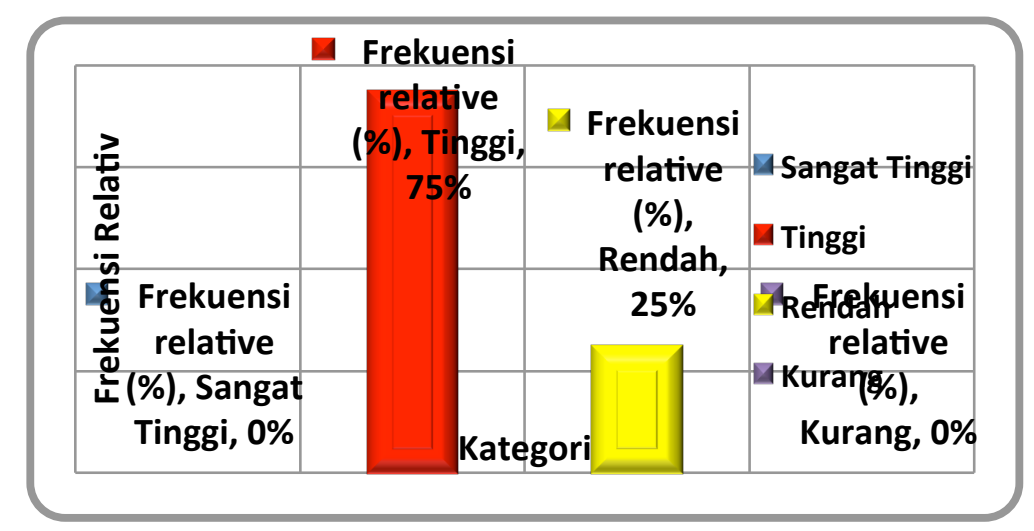

Gambar 1.Histogram Distribusi Frekuensi Kecenderungan Pemanfaatan Internet Sebagai Salah Satu Sumber Belajar Ditinjau Siswa Kelas X 
Hasil analisa data untuk tinjauan siswa kelas $\mathrm{X}$ dengan indikator kemampuan, proses pembelajaran, dan lingkungan, dapat diketahui tingkat pencapaian Pemanfaatan Internet Sebagai Salah Satu Sumber Belajar Siswa dan Guru. Diperoleh rentang skor 83 sampai dengan 137; Mean sebesar 112.31; Median sebesar 110.50; Modus sebesar 109 dan Standar Deviasi sebesar 13.194. Berpedoman kategori tabel kecenderungan hasil analisa kelas $\mathrm{X}$ didapatkan sangat tinggi sebanyak 0 siswa atau $0 \%$, tinggi sebanyak 24 siswa atau $75 \%$, rendah sebanyak 8 siswa atau $25 \%$ dan 0 siswa pada kategori kurang. Dari hasil tabel dan histogram kecenderungan siswa kelas $\mathrm{X}$ terhadap tingkat pemanfaatan internet sebagai salah satu sumber belajar siswa dan Guru berada pada ketegori tinggi sebesar $75 \%$.

Hasil bahwa Pemanfaatan Internet Sebagai Salah Satu Sumber Belajar Ditinjau Dari Siswa Kelas XI yang memiliki kategori sangat tinggi sebanyak 3 siswa atau 9.68\%, kategori tinggi sebanyak 24 siswa atau 77,42\%, kategori rendah sebanyak 4 siswa atau $12.90 \%$, serta 0 siswa atau $0 \%$ dalam kategori kurang. Jadi secara umum Pemanfaatan Internet Sebagai Salah Satu Sumber Belajar Ditinjau Dari Siswa Kelas XI mempunyai kecenderungan dalam kategori tinggi.

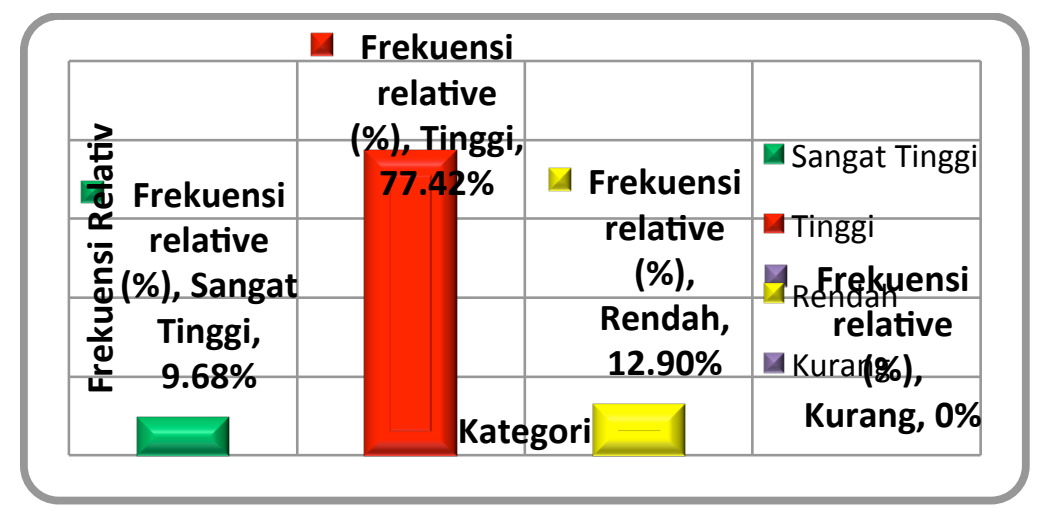

Gambar 2.Histogram Distribusi Frekuensi Kecenderungan Pemanfaatan Internet Sebagai Salah Satu Sumber Belajar Ditinjau Siswa Kelas XI

Hasil analisa data untuk tinjauan siswa kelas XI dengan indikator kemampuan, proses pembelajaran, lingkungan, dan sarana prasarana dapat diketahui tingkat pencapaian Pemanfaatan Interenet Sebagai Salah Satu Sumber Belajar Siswa dan Guru. Diperoleh rentang skor 100 sampai dengan 152; Mean sebesar 122.61; Median sebesar 122.00; Modus sebesar 122 dan Standar Deviasi sebesar 12.532. Berpedoman pada tabel distribusi frekuensi kecenderungan, hasil analisa data kelas XI didapatkan sangat tinggi sebanyak 3 siswa atau $9.68 \%$, tinggi sebanyak 24 siswa atau $77.42 \%$, rendah sebanyak 4 siswa atau $12.90 \%$ dan 0 siswa pada ketegori kurang. Dari hasil tabel dan histogram 
kecenderungan siswa kelas XI terhadap tingkat pemanfaatan internet sebagai salah satu sumber belajar siswa dan guru berada pada ketegori tinggi sebesar $77.42 \%$.

Hasil bahwa Pemanfaatan Internet Sebagai Salah Satu Sumber Belajar Ditinjau Dari Siswa Kelas XII yang memiliki kategori sangat tinggi sebanyak 5 siswa atau $15.63 \%$, kategori tinggi sebanyak 23 siswa atau $71.88 \%$, kategori rendah sebanyak 4 siswa atau $12.50 \%$, serta 0 siswa atau $0 \%$ dalam kategori kurang. Jadi secara umum Pemanfaatan Internet Sebagai Salah Satu Sumber Belajar Ditinjau Dari Siswa Kelas XII mempunyai kecenderungan dalam kategori tinggi.

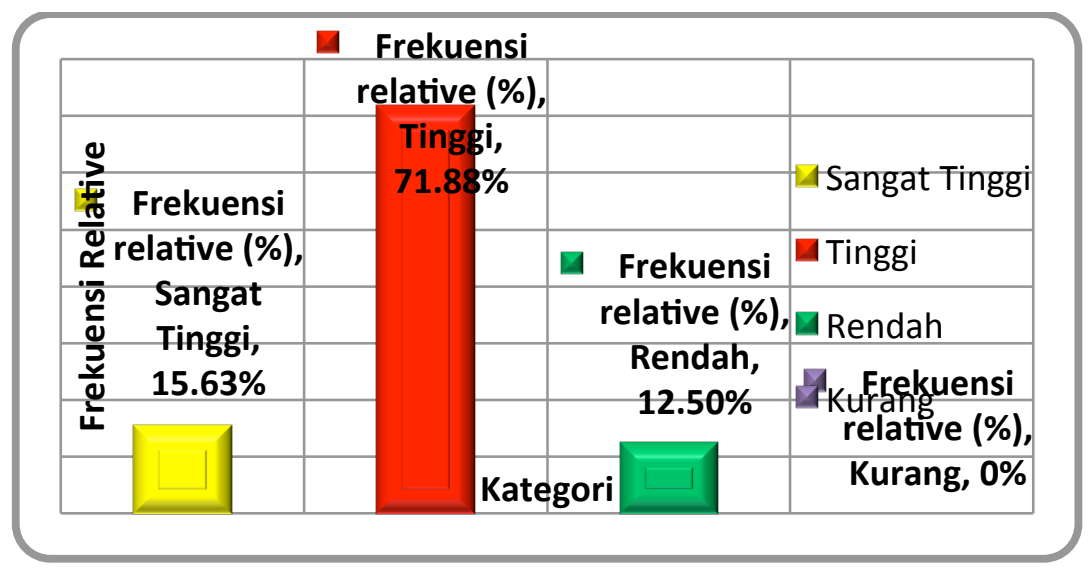

Gambar 3.Histogram Distribusi Frekuensi Kecenderungan Pemanfaatan Internet Sebagai Salah Satu Sumber Belajar Ditinjau Siswa Kelas XII

Hasil analisa data untuk tinjauan siswa kelas XII dengan indikator kemampuan, proses pembelajaran, lingkungan, dan sarana prasarana dapat diketahui tingkat pencapaian Pemanfaatan internet sebagai salah satu sumber belajar siswa dan guru. Diperoleh rentang skor 79 sampai dengan 147; Mean sebesar 125.31; Median sebesar 124.00; Modus sebesar 119 dan Standar Deviasi sebesar 15.243. Berpedoman pada tabel distribusi frekuensi kecenderungan, hasil analisa data kelas XII didapatkan sangat tinggi sebanyak 5 siswa atau $15.63 \%$, tinggi sebanyak 23 siswa atau $71.88 \%$, rendah sebanyak 4 siswa atau $12.5 \%$, dan $0 \%$ pada kategori kurang. Dari hasil tabel dan histogram kecenderungan siswa kelas XII terhadap tingkat pemanfaatan internet sebagai salah satu sumber belajar siswa dan guru berada pada ketegori tinggi sebesar $71.88 \%$. 


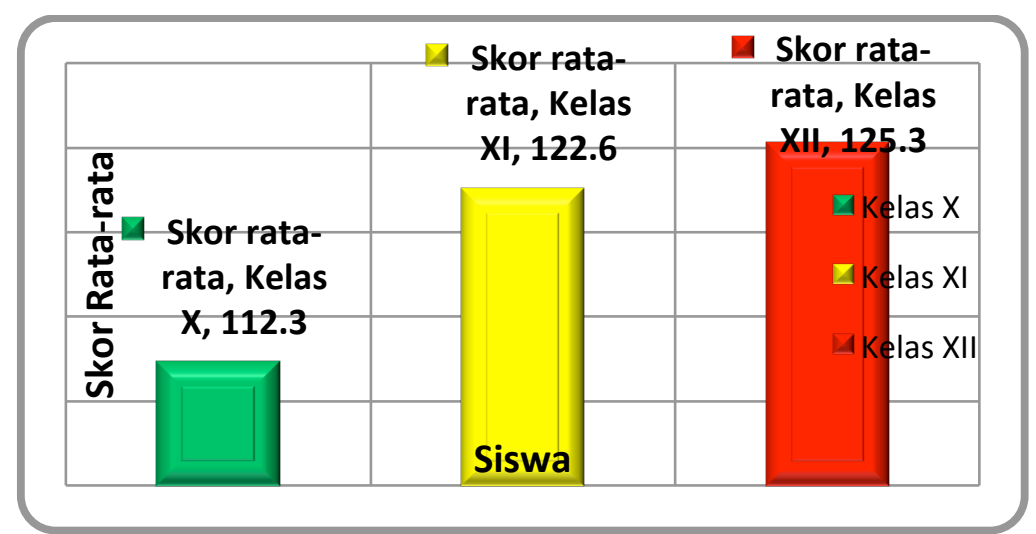

Gambar 4.Histogram Perbandingan Skor Rata-Rata Pemanfaatan Internet Sebagai Salah Satu Sumber Belajar Keseluruhan Siswa Elektronika

Pemanfaatan Internet Sebagai Salah Satu Sumber Belajar Ditinjau Dari Guru yang memiliki kategori sangat tinggi sebanyak 1 guru atau $11.11 \%$, kategori tinggi sebanyak 6 guru atau $66.66 \%$, kategori rendah sebanyak 2 guru atau $22.22 \%$, serta 0 guru atau 0\% dalam kategori kurang. Jadi secara umum Pemanfaatan Internet Sebagai Salah Satu Sumber Belajar Ditinjau Dari Segi Guru mempunyai kecenderungan dalam kategori tinggi.

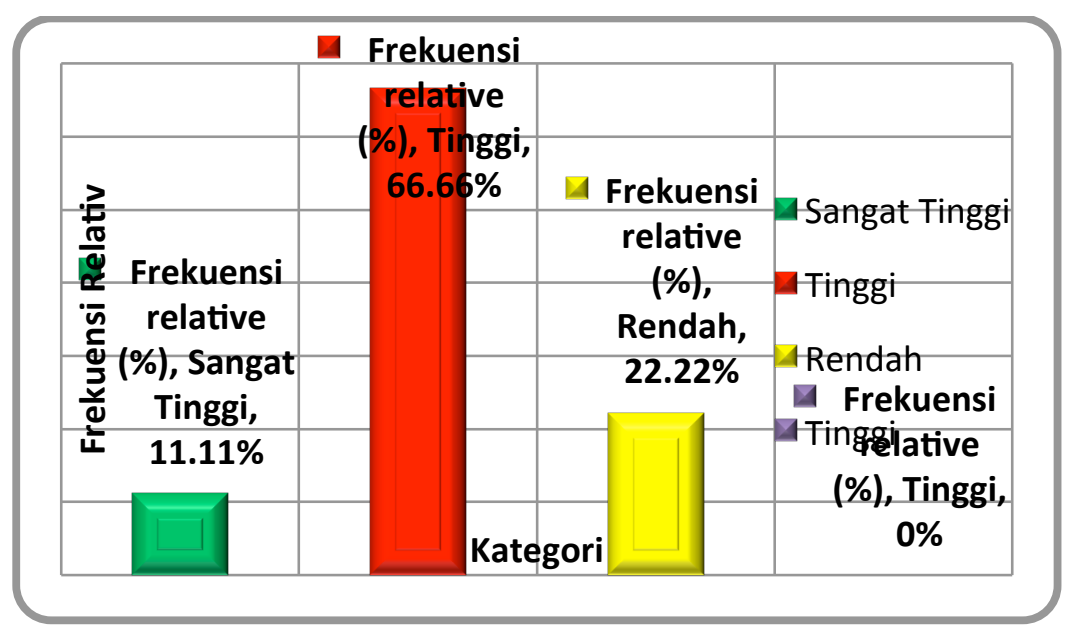

Gambar 5.Histogram Distribusi Frekuensi Kecenderungan Pemanfaatan Internet Sebagai

Salah Satu Sumber Belajar Ditinjau Dari Segi Guru

Dari tabel 5. maka dapat diketahui bahwa pemanfaatan internet sebagai salah satu sumber belajar ditinjau dari segi guru diperoleh sebanyak $66.66 \%$ termasuk dalam kategori tinggi. Dengan melihat perolehan nilai pemanfaatan internet sebagai salah satu sumber belajar dari aspek guru memberikan hasil yang hampir signifikan dengan hasil dari para siswa. Berdasarkan nilai yang diperoleh pada butir soal yang mengungkap 
pemanfaatan internet sebagai salah satu sumber belajar siswa dan guru dapat dikatakan bahwa antara siswa dan guru dalam mengggunakan fasilitas internet untuk keperluan pembelajaran bisa dikatakan tinggi sehingga semakin optimal penggunaan fasilitas tersebut sebagai salah satu sumber belajar yang ditinjau dari indikator kemampuan, proses pembelajaran, dan lingkungan.

Dari analisa data yang dilakukan mengenai hambatan siswa dalam penggunaan internet sebagai salah satu sumber belajar menurut para siswa, bahwa sebanyak $69.47 \%$ siswa mengatakan bahwa hambatan dari aspek sarana prasarana pada kategori rendah. Setelah melihat hasil analisa dan tabel kecenderungan pada masing-masing butir soal yang mengungkap hambatan dalam penggunaan internet sebagai salah satu sumber belajar siswa dan guru maka secara umum dapat dikatakan hambatan siswa dalam penggunaan internet sebagai salah satu sumber belajar dapat dikategorikan rendah dari segi sarana prasarana.

Selain dari segi sarana prasarana hambatan penggunaan internet sebagai salah satu sumber belajar siswa juga berasal dari dalam internet tersebut. Dikarenakan para siswa-siswi lebih cenderung mengakses situs-situs pertemanan, seperti: facebook, twitter, ym dan juga situs-situs di internet yang menawarkan hiburan. Dari analisa data yang dilakukan kecenderungan siswa mengakses situs-situs tersebut karena adanya ajakan dari teman-teman sebaya dan juga sebagai media untuk mengeksiskan diri. Hambatan dari situs-situs internet inilah yang menjadi penghambat yang cukup tinggi di dalam pemanfaatan internet sebagai salah satu sumber belajar siswa karena bisa menyebabkan berkurangnya waktu belajar siswa dan menurunkan produktifitas belajar siswa itu sendiri

Tidak hanya dari segi sarana prasarana, hambatan pemanfaatan internet sebagi salah satu sumber belajar guru juga berasal dari situs-situs yang terdapat di internet. Dari hasil data yang diperoleh mengenai hambatan penggunaan internet sebagai sumber belajar yaitu para guru yang ada di Jurusan Teknik Elektronika sudah menggunakan internet untuk keperluan tertentu saja, misalnya mencari bahan pelajaran, tambahan materi, dan juga sudah digunakan sesuai dengan kebutuhanya. Untuk situs-situs yang menawarkan hiburan, para guru mempergunakannya disaat di perlukan saja dalam artian tidak setiap saat mengakses situs tersebut.

\section{Penutup}

Berdasarkan hasil analisa dan pembahasan hasil penelitian dapat disimpulkan sebagai berikut: 
a. Hasil analisa deskriptif menunjukkan bahwa pemanfaatan internet sebagai salah satu sumber belajar siswa dan guru yang ditinjau dari segi siswa mendapatkan hasil yaitu untuk siswa kelas X sebesar 75\%, kelas XI sebesar 77.42\% dan kelas XII sebesar $71.88 \%$ dari hasil analisa data dapat dikategorikan tinggi. Dimana fasilitas internet yang ada di sekolah maupun dilingkungan sekolah sudah optimal penggunaannya sebagai salah satu sumber belajar siswa.

b. Hasil analisa deskriptif menunjukkan bahwa pemanfaatan internet sebagai salah satu sumber belajar siswa dan guru yang ditinjau dari segi guru secara umum dapat dikatakan tinggi penggunaan internet sebagai salah satu sumber belajar dengan pencapaian sebesar $66.66 \%$. Artinya fasilitas yang disediakan sekolah untuk dewan guru sudah optimal penggunaanya sebagai salah satu sumber belajar guru, yang mana bisa digunakan untuk meningkatkan dan menambah wawasan ilmu pengetahuan untuk diberikan kepada para siswa.

c. Dari hasil analisa data menunjukkan bahwa hambatan yang dihadapai oleh para siswa dalam menggunakan internet sebagai salah satu sumber belajar sebesar $66.47 \%$ berada pada kategori rendah dari segi sarana prasarana ini berarti fasilitas yang ada disekolah, lingkungan sekolah dan tempat tinggal sudah bisa dimanfaatkan dengan baik dan optimal sehingga dapat digunakan sebagai salah satu sumber belajar untuk menunjang materi belajar maupun pembelajaran di sekolah. Selain hambatan dari sarana prasarana, faktor-faktor penghambat pemanfaatan internet sebagai salah satu sumber belajar siswa yaitu makin banyaknya situs-situs yang beredar di internet menawarkan hiburan dan konten-konten pertemanan, seperti facebook, twitter yang dapat menurunkan produktifitas belajar dan berkuranya waktu belajar siswa.

d. Hasil analisa data mengenai hambatan guru dalam menggunakan internet sebagai salah satu sumber belajar sebesar $77.77 \%$ berada pada kategori rendah dilihat dari segi sarana prasarana. Hasil ini memberikan kesimpulan bahwa fasilitas untuk menunjang internet sebagai salah satu sumber belajar memadai dan digunakan cukup maksimal untuk pembelajaran guru di sekolah.

e. Hambatan lain yang juga mempengaruhi pemanfaatan internet sebagai salah satu sumber belajar yaitu berasal dari dalam internet itu sendiri, dimana situs-situs yang beredar di internet lebih banyak menawarkan hiburan, antara lain situs pertemanan facebook, twitter, yahoo messenger. Untuk itu perlu kesadaran dari diri sendiri saat mengakses informasi dari internet dimana untuk para guru lebih diutamakan mengakses internet untuk memperoleh materi pelajaran dan tambahan bahan pelajaran di sekolah. 
Berdasarkan kesimpulan penelitian diatas, maka saran yang dapat disampaikan yaitu:

a. Memperhatikan potensi internet dan dampaknya apabila dimanfaatkan secara terencana dalam kegiatan pembelajaran, maka sudah waktunya dimulai upaya perintisan pemanfaatan internet untuk kepentingan kegiatan pembelajaran di sekolah. Dalam kaitan ini, perlu dilakukan sosialisasi dan penyiapan sekolah, baik yang berkaitan dengan sumber daya manusianya maupun fasilitas atau peralatan yang diperlukan. Pemerintah Kota/Kabupaten disarankan agar mendorong sekolah-sekolah yang telah memiliki kesiapan untuk memulai pemanfaatan internet dalam kegiatan pembelajaran.

b. Mengingat besarnya potensi internet yang dapat dimanfaatkan untuk kepentingan pembelajaran, maka seyogianya para guru dapat menjadikannya sebagai salah satu sumber belajar dan memanfaatkannya dalam kegiatan belajar-mengajar (KBM). Para guru juga diharapkan dapat merencanakan pemanfaatan internet dalam kegiatan belajar-mengajar secara teratur sehingga peserta didik mendapatkan pengalaman belajar dari sumber belajar di luar guru yang berhubungan dengan materi pelajaran. Dalam kaitan ini, peran atau dukungan dari Kepala Sekolah selaku pengelola sekolah diharapkan dapat memfasilitasi pemanfaatan media internet untuk pembelajaran dan sekaligus juga memberikan kesempatan kepada para guru untuk mengikuti pelatihan mengenai pengembangan dan pemanfaatan internet bagi kepentingan pembelajaran.

\section{DAFTAR PUSTAKA}

Arief Achmad. (2004). Pemanfaatan Media Massa Sebagai Sumber Pembelajaran IPS Di Tingkat Persekolahan. http://re-searchengines.com/mangkoes6-04-2.html (Online) tanggal 25 Agustus 2015 jam 4.49 PM

Mulyasa, E. (2006). Implementasi Kurikulum 2004 Panduan Pembelajaran KBK. Bandung : PT Remaja Rosdakarya.

Mulyasa. (2005). Manajemen Berbasis Sekolah. Bandung: PT Remaja Rosdakarya.

Mulyasa. (2009). Menjadi Guru Profesional Menciptakan Pembelajaran Kreatif dan Menyenangkan. Bandung: PT Remaja Rosdakarya.

Ratna Wilis Dahar. (1996). Teori-Teori Belajar. Jakarta: Erlangga.

Sudiarman Siahaan dan Rr Martiningsih. (2009). Pemanfaatan Internet dalam Kegiatan Pembelajaran di SMP Al Muslim Sidoarjo-Jawa Timur. 